pro-evolution vote in rural areas was Pat Ross, an assistant professor of biology at Southwestern College in the small town of

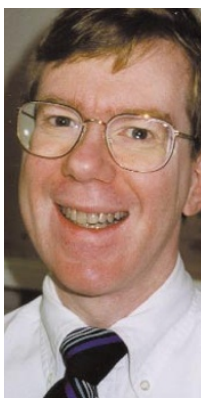

Buechner: spent this summer campaigning.
Winfield, Kansas. A member of Kansas Citizens for Science, Ross campaigned and helped organize a faculty vote against the state board's anti-evolution stance.

Southwestern is affiliated with the Methodist church, and was the only religious college in the state to have the faculty take such a position. "Typically, researchers are so immersed in their

own science that they assume people will see the light, so scientists don't need to get involved," says Ross. "This experience shows us scientists need to go outside their institutions and classrooms."

Another researcher who left the lab to fight the creationists was Matthew Buechner, a cell biologist at the University of Kansas. Appalled by the state board's actions, Buechner spent this summer campaigning door-to-door in conservative voting districts.

Buechner has already signed up to help with long-term education efforts for highschool teachers - the next phase of : activism by Kansas Citizens for Science.

\title{
German scientists pledge to fight growing xenophobia
}

Quirin Schiermeier \& Ute Gitschel, Munich

In a bid to counter the impression that foreign researchers face an unfriendly reception, Germany's scientific community has promised to fight the country's growing reputation for intolerance towards foreigners.

There have been several attacks and verbal assaults in the past months on foreign scientists and their families in east Germany. In Saxony, a young scientist was badly injured when right-wing extremists set their dog on him. Scientists have also been attacked in Gaterslaben and Frankfurt/Oder.

In an open letter published last week in German national newspapers, scientific institutes across the country warned that xenophobia and racism could threaten Germany's attractiveness to foreign scientists.

The letter's signatories include Hubert Markl, president of the Max Planck Society, and Frank Pobell, president of the Wissenschaftsgemeinschaft Gottfried Wilhelm Leibniz (WGL), an association of 80 research and service institutes. Several hundred foreign researchers come to Max Planck and WGL institutes in east Germany each year.

"Foreign scientists feel increasingly unsafe, particularly in eastern Germany," says
Falk Fabich, director of the Forschungsverbund Berlin, an association of eight Berlinbased WGL institutes that employ 85 foreign researchers and host around 300 guest researchers each year.

Fabich, who initiated the anti-racism campaign, says scientists are becoming "increasingly hesitant" about coming to Germany. For example, he says, the Alexander von Humboldt Foundation, which awards grants to foreign scholars, finds it increasingly difficult to arrange fellowships in east Germany. A programme director at the foundation says that fear of racist attack is "one of the reasons" people prefer to go elsewhere.

"If you look Asian or dark-skinned, you can feel the tension as soon as you leave the institute," says Dierk Scheel, director of the Institute for Plant Biochemistry in Halle, which has hosted Humboldt scholars from Asian countries in previous years.

Many German scientists are promising to fight against xenophobia. The Institute for Innovative Microelectronics in Frankfurt/ Oder in east Germany, for example, has organized meetings with schoolchildren to explain the economic benefits of international collaboration.

\section{Internet is the new key for restructured film institute}

Since the pioneering days of cinematography, film has been used by scientists to document, analyse and teach about complex phenomena, from the social behaviour of tribes to the growth of tumour cells.

But many national and private audiovisual service institutions - including those in the Netherlands, Austria, Hungary and Japan - have been closed over the past decade owing to the high cost of storing, preserving and distributing celluloid film.

Two years ago, Germany's only institute for scientific film, the Institut für den Wissenschaftlichen Film (IWF) in Göttingen, faced a similar fate. Its days seemed numbered after Germany's science council, the Wissenschaftsrat, criticized its failure to invest in new electronic media, and recommended that federal funding be withdrawn (see Nature 391, 425; 1998).

But a strategy based on embracing the opportunities offered by the Internet - and a $50 \%$ cut in its annual budget, provided jointly by federal and regional governments, to DM7 million (US\$3.2 million) - has helped the IWF to survive. The institute has now begun to create an online video library

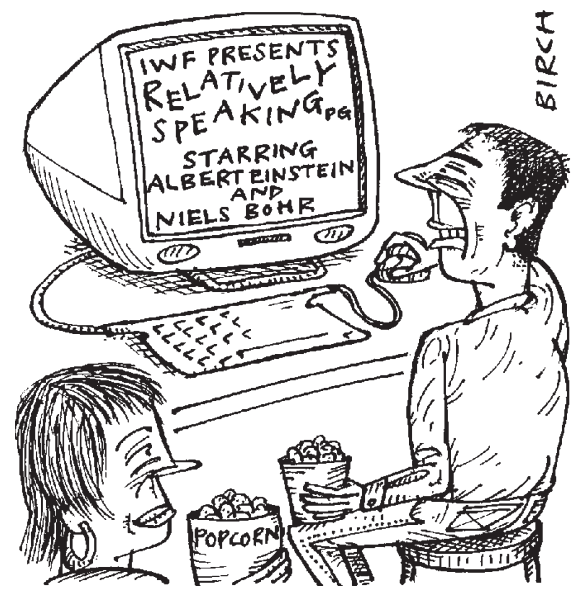

that is available to scientists, science teachers, film editors and producers worldwide.

The federal research ministry last month approved an additional DM5 million grant for the digitalization of the IWF's collection of around 7,000 films and video tapes, 5,000 of which were made at the IWF. Most of these recordings are visual aids for research and edycation in manyareas of science, medicine, anthropology and psychology.
Digitalization will start with the IWF's 400 most frequently requested films, including recordings of the activities in potassium ion channels and of material transport by North Sea currents.

These films, to be cut into about 1,000 two-minute sequences, will be online next spring, says Hartmut Rudolph, the institute's scientific director. By 2005, around 30,000 minutes of film should be available on the Internet, he says. The content of all available recordings will be scientifically annotated, and orders for clips will be taken online.

The IWF will no longer receive a fixed budget for producing new films, but must generate its own revenue. Rudolph hopes that the Internet library will help increase sales to commercial users. "We will of course continue to be a service institute for scientists," says Rudolph. "But financially we have become increasingly dependent on licensing our films to commercial users."

The institute is already licensing recordings to TV stations in Germany and to the BBC in Britain. http://wwww.iwf.de 